\title{
Correlation between Circulatory and Salivary IL 10 Levels in Periodontal Health and Disease - A Report
}

\author{
Archana $^{1}$, Sasireka $^{2}$, M.N Prabhu ${ }^{3}$, Bobby $^{4, *}$, Venkata Srikanth $^{4}$ \\ ${ }^{1}$ Department of Periodontics, Madha Dental College, Chennai,India \\ ${ }^{2}$ Department of Periodontics, Adhiparasakthi Dental College, Melmaruvathur, India \\ ${ }^{3}$ Departmentof Periodontics, Penang International Dental College, Malaysia \\ ${ }^{4}$ Department of Periodontics, Adhiparasakthi Dental College, Melmaruvathur, India \\ *Corresponding author: bobbds2000@gmail.com
}

Received July 26, 2014; Revised August 12, 2014; Accepted August 18, 2014

\begin{abstract}
Interleukin (IL)-10 is an important immunoregulatory cytokine produced by many cell populations. Its main biological function seems to be the limitation and termination of inflammatory responses and the regulation of differentiation and proliferation of several immune cells such as $\mathrm{T}$ cells, B cells, natural killer cells, antigenpresenting cells, mast cells, and granulocytes. The present study has correlated the salivary IL-10 levels with that of the circulatory levels in periodontal health and diseased patients and also brings an attestation for Saliva as point of care diagnosis.
\end{abstract}

\section{Keywords: interleukins, pro inflammatory cytokines, anti inflammatory cytokines $T h_{1}, T h_{2}, G C F$}

Cite This Article: Archana, Sasireka, M.N Prabhu, Bobby, and Venkata Srikanth, "Correlation between Circulatory and Salivary IL 10 Levels in Periodontal Health and Disease - A Report." International Journal of Dental Sciences and Research, vol. 2, no. 4B (2014): 7-10. doi: 10.12691/ijdsr-2-4B-3.

\section{Introduction}

Periodontal Disease is a chronic inflammatory condition, characterized by loss of hard and soft tissues of the tooth supporting structures. Although microbial in origin, the destruction of the tissues is the result of an exaggerated host response $[2,4]$. Complex inflammatory and immune responses are involved in the progression of periodontal disease. $\mathrm{B}$ cells and $\mathrm{T}$ cells accumulate in large numbers in the periodontal tissues, although until recently we have had little information on cellular synthetic activity and proliferation of these cells. [7] When an assessment is made of the role that different cell types play in the sites of inflammation one must be wary of the limitations imposed by merely observing morphology and phenotypic cell surface markers. Gemmell \& Seymour [18] have shown an increased proportion of $\mathrm{T}$ cells as the infiltrate increases in diseased gingival tissues. Others have shown an increase in $\mathrm{T}$ cell numbers in peripheral blood and it has been suggested that homing of these cells to the gingiva may occur during the disease process [5]. The specific $\mathrm{T}$ cells proliferate locally within certain tissues, giving rise to characteristic $\mathrm{T}$ cell clones for these regions $[1,12,15]$.

Analysis of the cytokine profiles of the $\mathrm{T}$ cell subsets Th1 and Th2 in periodontal tissues have been made using distinctly different strategies. Gemmell \& Seymour [17] performed FACs analysis of leucocytes extracted from periodontal tissues, while Yamazaki et al [34]. used an Immunochemical method is used to detect the cells in periodontal lesions, and a cell blotting technique to trap and identify IL-2- and IL-4-expressing T cells.

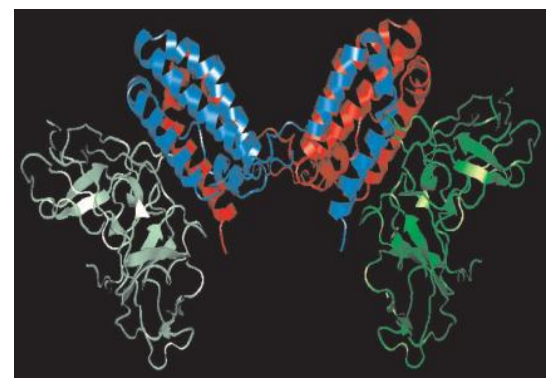

Figure 1. Three - dimensional Structure of IL 10

\section{IL-10 \& its biological effects:}

IL -10 a Negative Feedback Regulator: Immunomodulator

1. Produced mainly by activated macrophages and regulatory $\mathrm{T}$ cells

2. Inhibitor of activated macrophages and dendritic cells and is thus involved in the control of Innate Immune Reactions and Cell Mediated Immunity [6,9]

3. Thus serves as Immunoregulatory cytokine stimulating innate immunity and $\mathrm{Th} 2$ responses while suppressing Th1 responses (inflammation associated) [14].

\section{Cytokines in Serum}

1. Up regulation of pro inflammatory cytokines not only lead to tissue destruction in inflammed gingival 
tissues but also result in a systemic spill over, and thereby modulate the course of several systemic diseases viz. CVD, RA, diabetes etc.(Offenbacher et al 1998) [30]

2. Elevated levels of several pro inflammatory cytokines such as TNFa IL-1, IL-6, have been reported, but the role of the anti inflammatory cytokines, in circulation has not yet been fully elucidated.(Miller et al) [27].

\section{Saliva - A Diagnostic Tool}

Saliva has been used as a noninvasive vehicle to monitor progression and treatment outcome of several diseases including periodontal disease. Recently, oral fluid based "point of care" diagnostics, based on microfluidic assays are being adapted for its potential chair side use in periodontal disease

\section{i. Aim of the Study:}

1. Evaluation of circulatory levels of IL-10 \& hs CRP in Periodontal health and disease

2. Evaluation of salivary IL-10 levels and its relationship to its circulatory levels

ii. Materials and Methods:

Sample population:

Total 30 patients (Periodontally health \& disease)- out patient pool of Ragas Dental College.

Sample Collection:

a. Blood- from the antecubital fossa, serum separation was done by centrifugation.

b. Saliva $-5 \mathrm{ml}$ of whole unstimulated saliva was collected by spitting method, centrifuged at $2500 \mathrm{rpm}$ for 10 mins, stored in $-80^{\circ} \mathrm{C}$ till further use.

c. Both blood and unstimulated saliva samples were obtained prior to treatment.

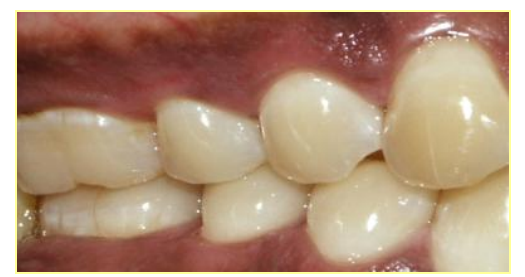

Figure 2. Healthy gingiva

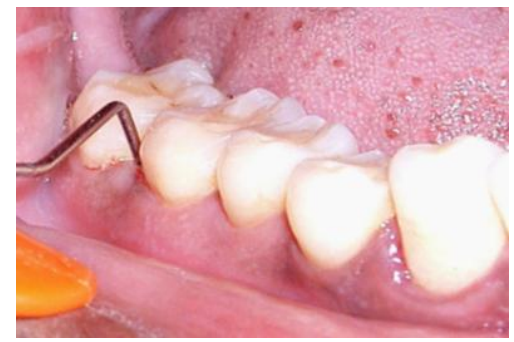

Figure3. Healthy gingiva

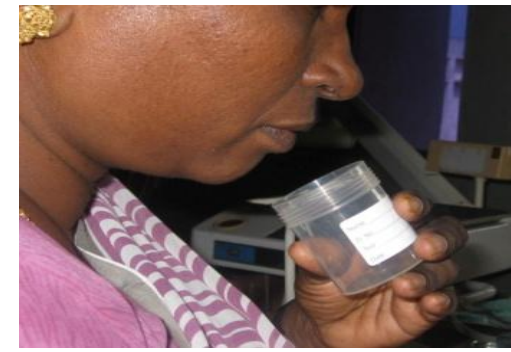

Figure 4. Saliva Sample

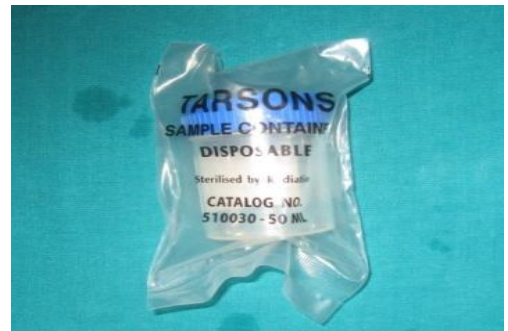

Figure 5. Saliva Sample

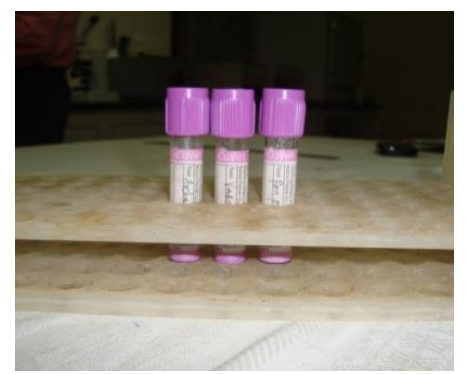

Figure 6. Sterile Container to collect saliva

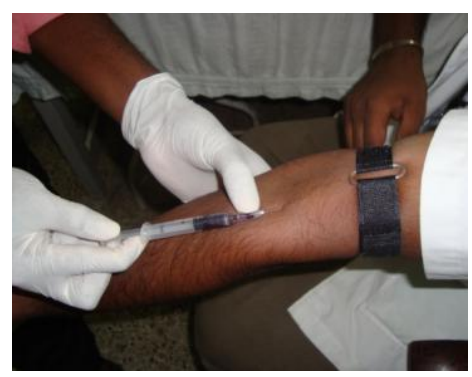

Figure 7. Blood Sample Collection from Ante cubetal fossa

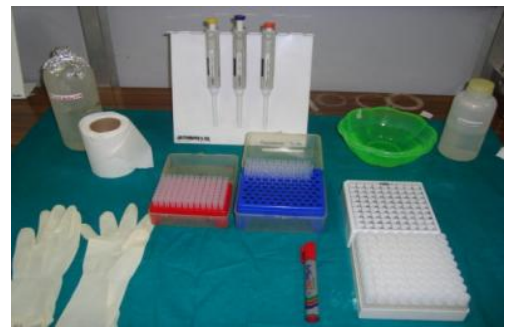

Figure 8. Armamentarium used for Blood sample collection

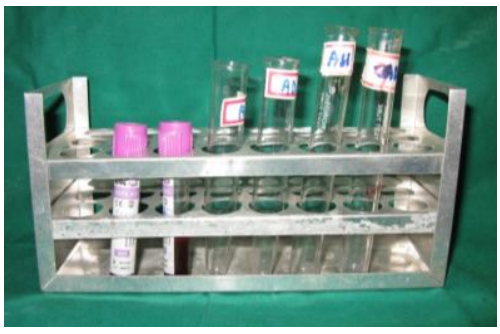

Figure 9. Armamentarium for centrifuge

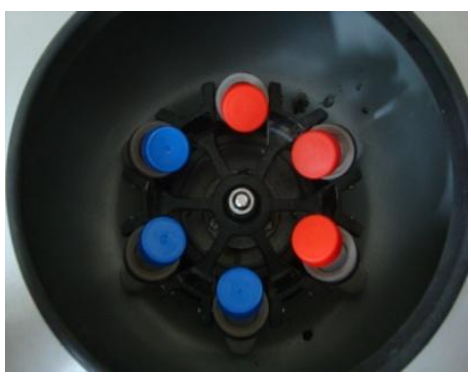

Figure 10. Centrifuge 


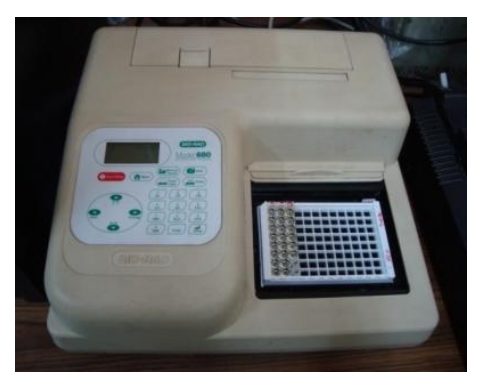

Figure 11. Microplate

Serum hsCRP levels- evaluated by immunoturbidity method (private laboratory).

ELISA Assay

Serum \& salivary IL-10 levels evaluated by sandwich ELISA method.

Prepare all reagents and standards as required.

Add $100 \mu 1$ of assay diluent to each well

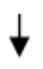

Add $100 \mu 1$ of standard, control or sample to each well.

(Incubate for 3 hours )

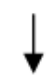

Aspirate and wash 3 times

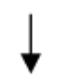

Add $200 \mu 1$ conjugate to each well. Incubate for 1 hour.

Aspirate and wash 3 times

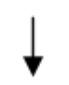

Add $200 \mu 1$ substrate solution to each well. Incubate for 30 minutes (Protect from light)

\section{Results}

\begin{tabular}{|c|c|c|c|}
\hline & $\begin{array}{c}\text { hs CRP } \\
(\mathrm{mg} / \mathrm{l})\end{array}$ & $\begin{array}{c}\text { IL10 (Serum } \\
\text { levels }) \\
(\mathrm{pg} / \mathrm{ml})\end{array}$ & $\begin{array}{c}\text { IL10 (Salivary } \\
\text { Levels }) \\
(\mathrm{pg} / \mathrm{ml})\end{array}$ \\
\hline $\begin{array}{c}\text { Health } \\
(\text { Mean } \pm \text { SEM) }\end{array}$ & $1.16 \pm 0.033$ & $33.7 \pm 2.7$ & $88.7 \pm 5.1$ \\
\hline $\begin{array}{c}\text { Disease } \\
(\text { Mean } \pm \text { SEM) }\end{array}$ & $2.25 \pm 0.29$ & $26.1 \pm 2.3$ & $74.5 \pm 3.6$ \\
\hline P Value & 0.024 & 0.045 & 0.036 \\
\hline
\end{tabular}

1. A statistically significant $(\mathrm{p}<0.05)$ increase of serum hs-CRP levels was observed in of serum hs-CRP levels was observed in

2. periodontal disease when compared to health.

3. Statistically significant $(\mathrm{p}<0.05)$ decrease of serum IL-10 levels in periodontal disease when compared to health

4. Negative correlation between serum hs -CRP and IL10 levels was observed which was not statistically significant.

5. Statistically significant $(\mathrm{p}<0.05)$ decrease of salivary IL-10 levels in periodontal disease when compared to health

\section{Discussion}

A systemic inflammatory state has been reported when there is a dysregulation in the balance between the pro inflammatory and anti inflammatory cytokine levels (Ritter et al 1999) [32] A preponderance of pro inflammatory cytokine in disease has been documented in several studies but the down regulation of the anti inflammatory cytokines has not been widely documented However decreased levels of IL-4 in the GCF has been reported by Giannobile et al 1998 [22] following periodontal disease. These authors conclude that downregulation of the anti inflammatory IL-4 would have contributed to the prolonged inflammation observed in periodontal tissues. Several lines of evidence suggest a role for IL-10 in periodontal disease pathogenesis:

- Regulate immune responses

- IL-10 gene polymorphism associated with disease severity

IL-10 gene knock out mice exhibit increased osteoclastogenesis and bone loss [28].

This study also shows a down regulation of circulatory anti inflammatory cytokine IL-10 in periodontal disease in accordance with the Giannobile study [21] This could have contributed to the systemic inflammatory state, as shown by increase of hs- CRP observed in our patients. However as the correlation was not statistically significant other contributing factors may also play a role [20]. There is thus a need for simultaneous assessment of several pro and anti nflammatory cytokines to predict the systemic inflammatory status accurately. There was also a significant decrease of Salivary IL-10 levels in Periodontal disease and this correlates strongly to the circulatory hs-CRP Saliva may therefore truly reflects the systemic inflammatory state evoked by Periodontal disease [23].

\section{Conclusion}

Salivary IL-10 levels may reflect the systemic inflammation observed in periodontitis.Hence saliva may be used as a non-invasive chair side diagnostic tool for systemic status evaluation of periodontal patients. A larger sample size with a longitudinal assessment of a cocktail of pro and anti inflammatory cytokines may provide greater strength to this hypothesis. 


\section{References}

[1] Allavena P, Piemonti L, Longoni D, Bernasconi S, Stoppacciaro A, Ruco L, and Mantovani A (1998) IL-10 prevents the differentiation of monocytes to dendritic cells but promotes their maturation to macrophages. Eur J Immunol 28: 359-369.

[2] Andersen SR, Lambrecht LJ, Swan SK, Cutler DL, Radwanski E, Affrime MB, and Garaud JJ (1999) Disposition of recombinant human interleukin-10 in subjectswith various degrees of renal function. J Clin Pharmacol 39: 1015-1020.

[3] Aoyagi T, Sugawara-Aoyagi M, Yamazaki K, Hara K. Interleukin 4 (IL-4) and IL-6-producing memory T-cells in peripheral blood and gingival tissue in periodontitis patients with high serum antibody titres to Porphyromonas gingivalis. Oral Micrbiol Immunol 1995; 10: 304 10.

[4] Aurer Andrej, Ksenija Jorgi-Srdjak, Darije Planak, Ana StavljeniRukavina and Jelena Aurer-Ko elj Proinflammatory Factors in Saliva as PossibleMarkers for Periodontal Disease Coll. Antropol. 29 (2005) 2: 435-439

[5] Chernoff AE, Granowitz EV, Shapiro L, Vannier E, Lonnemann G, Angel JB, Kennedy JS, Rabson AR, Wolff SM, and Dinarello CA (1995) A randomized, controlled trial of IL-10 in humans. Inhibition of inflammatory cytokine production and immune responses. J Immunol 154: 5492-5499.

[6] Cooper PJ, Fekade D, Remick DG, Grint P, Wherry J, and Griffin GE (2000) Recombinant human interleukin-10 fails to alter proinflammatory cytokine production or physiologic changes associated with the Jarisch-Herxheimer reaction. J Infect Dis 181: 203-209.

[7] D'Andrea A, Aste-Amezaga M, Valiante NM, Ma X, Kubin M, and Trinchieri G (1993) Interleukin 10 (IL-10) inhibits human lymphocyte interferon gamma-production by suppressing natural killer cell stimulatory factor/IL-12 synthesis in accessorycells. $J$ Exp Med 178: 1041-1048.

[8] Defrance T, Vanbervliet B, Briere F, Durand I, Rousset F, and Banchereau J (1992) Interleukin 10 and transforming growth factor beta cooperate to induce anti- CD40-activated naive human B cells to secrete immunoglobulin A. J Exp Med 175: 671-682.

[9] Del Prete G, De Carli M, Almerigogna F, Giudizi MG, Biagiotti R, and Romagnani S (1993) Human IL-10 is produced by both type 1 helper (Th1) and type 2 helper (Th2) T cell clones and inhibits their antigen-specific proliferation and cytokine production. $J$ Immunol 150: 353-360.

[10] Delaleu N, Immervoll H, Cornelius J, Jonsson R. Biomarker profiles in serum and saliva of experimental Sjögren's syndrome: associations with specific autoimmune manifestations. Arthritis Res Ther. 2008; 10(1): R22. Epub 2008 Feb 20.

[11] Demangel C, Bertolino P, and Britton WJ (2002) Autocrine IL-10 impairs dendritic cell derived immune responses to mycobacterial infection by suppressing DC trafficking to draining lymph nodes and local IL-12 production. Eur J Immunol 32: 994-1002.

[12] Ebersole JL, Taubman MA. The protective nature of host responses in periodontal diseases. Periodontol 2000, 1994; 5: 112141.

[13] Ebersole Jl,Cappelli D Acute phase reactants in infections and inflammatory diseases Periodontol 2000 2000; 23: 19-49.

[14] Fujihashi K, Yamamoto M, Hiroi T, Bamberg TV, McGhee JR, Kiyono H. Selected Th-1 and Th-2 cytokine mRNA expression by CD4(1) T cells isolated from inflamed human gingival tissues. Clin Exp Immunol 1996; 103: $422 \pm 87$.

[15] Fukui M, Hinode D, Yokoyama M, Tanabe S, Yoshioka M Salivary immunoglobulin A directed to oral microbiology GroEL in patients with periodontitis and their potential protective role. Oral Microbiol Immunol 2006; 21:289-295.
[16] Gallagher G, Dickensheets H, Eskdale J, Izotova LS, Mirochnitchenko OV, Peat JD, Vazquez N, Pestka S, Donnelly RP, and Kotenko SV (2000) Cloning, expression and initial characterization of interleukin-19 (IL-19), a novel homologue of human interleukin-10 (IL-10). Genes Immun 1:442-450.

[17] Gemmell E, Marshall RI, Seymour GJ. Cytokines and prostaglandins in immune homeostasis and tissue destruction in periodontal diseases. Periodontol 2000 1997; 14: 112 \pm 43.

[18] Gemmell E, Seymour GJ. Cytokine profiles of cells extracted from humans with periodontal diseases. J Dent Res 1998; 77: 16+26.

[19] Gemmell E, Seymour GJ. gd T lymphocytes in human periodontal disease tissue. J Periodontol 1995; 66: 780 \pm 5 .

[20] Gerard C, Bruyns C, Marchant A, Abramowicz D, Vandenabeele P, Delvaux A, Fiers W, Goldman M, and Velu T (1993) Interleukin 10 reduces the release of tumor necrosis factor and prevents lethality in experimental endotoxemia. $J$ Exp Med 177: 547-550.

[21] Giannobile WV, Al-Shammari KF, Sarment DP. Matrix molecules and growth factors as indicators of periodontal disease activity. Periodontol 2000 2003: 31: 125-134.

[22] Giannobile WV, Beikler T, Kinney JS, Ramseier CA, Morelli T, Wong DT. Saliva as a diagnostic tool for periodontal disease: current state and future directions. Periodontol 2000. 2009; 50: 52

[23] Hart TC, Marazita ML, Schenkein HA, Brooks CN, Gunsolley JG,Diehl SR. No female preponderance in juvenile periodontitis after correction for ascertainment bias. J Periodontol 1991; 62: $745 \pm 9$.

[24] Jenkins JK, Malyak M, and Arend WP (1994) The effects of interleukin-10 on interleukin-1 receptor antagonist and interleukin-1 beta production in human monocytes and neutrophiles. Lymphokine Cytokine Res 13: 47-54.

[25] Lappin DF, Koulouri O, Radvar M, Hodge P, Kinane DF. Relative proportions of mononuclear cell types in periodontal lesions analyzed by immunohistochemistry. J Clin Periodontol 1999; 26: $183 \pm 9$.

[26] Manhart SS, Reinhardt RA, Payne JB, Seymour GJ, Gemmell E, Dyer JK, Petro TM. Gingival cell IL-2 and IL-4 in early onset periodontitis. J Periodontol 1994; 144: $662 Ð 6$.

[27] Miller, Foley JD, Bailey AL, Campell CL, Humphries RL, Christodoulides N, Floriano PN, Simmons G, Bhagwandin B, Jacobson JW, Redding SW, Ebersole JL, McDevitt JT. Current developments in salivary diagnostics.Biomark Med. 2010; 4(1): 171-89.

[28] Morse HR, Bidwell JL, and Raveche ES (1999) A poly(C) repeat polymorphism in the promoter of the IL-10 gene in NZB mice. Eur J Immunogenet 26: 377-378.

[29] Nagai A, Takahashi K, Sato $\mathrm{N}$ et al. Abnormal proportion of gd T cells in peripheral blood is frequently detected in patients with

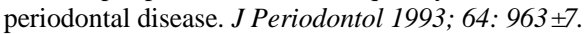

[30] Offenbacher S, Slade GD Beck JD, Heiss G, Pankow JS. Acutephase inflammatory response to periodontal disease in the US population. J Dent Res. 2000; 79(1): 49-57.

[31] Offenbacher, S.P.Barros, R.E.Singer, K.Moss, R.C. Williams, J.D. Beck. Periodontal disease at the biofilm-gingival interface. Journal of Periodontology.2007; 78: 1911-1925.

[32] Ritter M, Buechler C, Langmann T, Orso E, Klucken J, and Schmitz G (1999) The scavenger receptor CD163: regulation, promoter structure and genomic organization.Pathobiology 67: 257-26.

[33] Takahashi K, Poole I, Kinane DF. Detection of interleukin-1b mRNAexpressing cells in gingival crevicular fluid by in situ hybridization. Arch Oral Biol 1995; 40: $941 \pm 7$.

[34] Yamazaki K, Nakajima T, Hara K. Immunohistological analysis of $\mathrm{T}$ cell functional subsets in chronic inflammatory periodontal disease. Clin Exp Immunol 1995; 99: 384 \pm 91 . 